\title{
Manuscript Collections: James Norman Hall Papers, 1906-1951
}

\author{
Anne Genung Kintner
}

Grinnell College has long enjoyed an enviable reputation as one of the outstanding small liberal arts colleges in the country. Burling Library, too, has received just recognition: when first built on that magnificent green that flows out into the otherwise straight path of U.S. Highway Six, the library structure was one of the architectural wonders of Iowa. But, too few people have wandered to the beautiful room in the center of the lower level of the library. This well-appointed research room, flanked on one side by a storage vault, houses a surprisingly rich collection of manuscript materials, much of it concentrating on the history of the Congregational Church in Iowa. The Grinnell Room is an historical source whose riches are equalled only by the pleasant assistance provided by the archivist, Anne Kintner.-David Crosson, MS Collections Editor

Look to the northward, Stranger,

Just over the barn roof, there.

Have you in your travels seen

A land more passing fair? ${ }^{1}$

J AMES NORMAN HALL (1887-1951) wrote this poem about the turn of the century on the wall of the family woodshed (not

${ }^{1}$ James Norman Hall, My Island Home (Boston: Little Brown, 1952), 3. 
a part of the Grinnell College Archives collection) at the back of his home in Colfax, Iowa. A half century later the poem, with the words "barn roof" changed to "hillside," was inscribed on a bronze plaque marking Hall's grave on a hillside on Tahiti overlooking Matavai Bay where Captain Bligh anchored the Bounty in 1788. The teenage poet memorialized in these words the Iowa countryside he loved so much. The author who had lived in Tahiti for thirty years realized that, although he loved the island and its people and wanted to live nowhere else, he had become the Stranger looking northward to his midwestern roots, which could not be totally transplanted. ${ }^{2}$ Between his origins in quiet, peaceful lowa countryside and his years on the idyllic shore of Tahiti, Hall lived a successful life of adventure and travel.

Hall thought of himself as a poet, but most of us know him as a writer of adventure stories, most notably as co-author with Charles Nordhoff of Mutiny on the Bounty, Pitcairn's Island, and Men Against the Sea. Hall traveled widely and recorded in poems, essays, short stories, and novels impressions of his own and others' experiences in World War I, the Midwest, and the South Seas.

Grinnell College Archives received as a gift from Hall's two children much of the correspondence, manuscripts of writings, photographs, and clippings that were in Hall's study in Tahiti at the time of his death. The collection was augmented by gifts of letters and a few manuscripts from several close friends. The total collection in twenty-six document boxes, occupies ten linear feet of shelves.

As a boy Hall traveled on the cow tender of the engine number six, Chicago, Rock Island and Pacific train from Colfax to Grinnell, thirty miles east, where he roamed the college campus before catching the late night train back home. ${ }^{3}$ He later attended Grinnell College, and as a student traveled with the College Glee Club to the West Coast, a tour which he and D. W. Wilson described in "The Western Trip." After graduation in 1910 Hall became a social worker with the Boston Society for

${ }^{2}$ Hall, 3 .

${ }^{3}$ Hall, 7-10. 
the Prevention of Cruelty to Children. During these years he read widely, wrote (but published only three poems), and formed lasting friendships with Roy Cushing, probation officer in Juvenile Court, George C. Greener, teacher and later director of the North Bennet Street Industrial School, and Laurence L. Winship, reporter and later editor of the Boston Globe. Since Cushing and Greener acted as Hall's literary and business agents for much of the time Hall was out of the country, Hall wrote detailed letters to them about his writing and his activities, particularly during World War I. Greener was most active as Hall's literary agent during the 1920s, discouraging years when Hall could not publish enough to support his family. Both these friends donated their correspondence with and about Hall, as well as a few manuscripts and rejection slips, to Grinnell College.

Nineteen fourteen found Hall bicycling through Great Britain on a trip which proved to be of major significance for his career. He stopped at the home of Joseph Conrad near Ashford, in Kent, but diffidence prevented him from knocking at the door and meeting with the writer who had influenced him so profoundly. When war began in August, Hall was one of the many young men caught up in the idealism and excitement of the moment who joined the British Expeditionary Force. As a machine gunner in France he experienced the full horrors of trench warfare. In December 1915 he was discharged and returned to the United States to record his experiences in Kitchener's Mob, a book he hoped would help to jolt America out of its neutrality. Atlantic Monthly commissioned Hall to continue recording war experiences by returning to France and writing about the Lafayette Escadrille, a squadron of American volunteer airmen serving with the French. Instead of just observing and writing about the Escadrille, Hall joined them, became a pilot, engaged in numerous sorties for which he received decorations, was shot down and wounded several times. When the United States entered the war, Hall transferred to the U.S. Air Service with rank of Captain. Shot down in June 1918 behind the German lines and taken prisoner, he spent several months in a hospital with a broken ankle, then in various prisons, the last being Schloss Trausnitz in Landshut, Bavaria. His captors treated him well, 
and one them even provided him with a copy of Chaucer's Canterbury Tales, which he treasured, prolonging the pleasure by reading only one tale a week. This experience he later described in his book, Flying With Chaucer. A typescript description of Hall's prison experiences is in the College Archives along with a number of apologetic letters from editors explaining why they could not (in 1919) publish anything that was not strongly anti-German. Hall's correspondence with his family and friends, approximately 250 letters and post cards, and a newspaper clipping collection describe in detail his experiences, observations, and reactions to the war and to flying.

Immediately after the war Dr. Edmund Gros, one of the founders of the Lafayette Escadrille, commissioned Hall and Charles Nordhoff, who had not previously met, to write the history of the Escadrille. This they did on Martha's Vineyard in 1919 and published The Lafayette Flying Corps in 1920. Because of their tremendous disillusionment with postwar mechanization and its effects on society, Hall and Nordhoff in 1920 moved to Tahiti, seeking solitude and peace of mind. Travels through the South Seas on copra schooners led to a descriptive book, their second collaboration, Faery Lands of the South Seas. In 1922 Hall traveled to Iceland; although he anticipated writing a book on Iceland, only a few magazine articles appeared. Several small handwritten notebooks and photographs from this trip are in the Grinnell collection.

In 1923 Hall returned to establish his home in Tahiti, and in 1925 he married and later became the father of a son and a daughter. Though he and Nordhoff both wrote books and stories during the 1920s, success did not come until they collaborated on Mutiny on the Bounty (1932), the first of a number of South Seas adventure stories which established them as writers of note. About a fifth of the Hall collection at Grinnell consists of typescripts, some with revisions or several versions of sections, of nine of the twelve books Nordhoff and Hall coauthored. Approximately two-fifths of the collection contains parts or all of seven of the seventeen books Hall published alone; scripts of two of Hall's plays; typescripts or holograph versions of nineteen published stories and essays; and about 


\section{The Annals of Iowa}

sixty unpublished poems, stories, and essays, most undated. The Archives owns published copies of twenty-eight Hall and Nordoff-Hall books, including foreign-language editions of some titles. Clippings of book reviews, articles about the authors, about the South Seas, and of movies made from some of the books are also in the collection.

James Norman Hall continued for the rest of his life to travel extensively among the South Sea islands, to California, where his children were educated, and to Iowa and Boston. On one of these trips, of special importance to him, he received an honorary degree during his fortieth class reunion at Grinnell College in 1950.

Grinnell College Archives has over 650 letters and post cards from the years 1906-51, which include correspondence with his family and two of the Boston friends; letters to his former Grinnell professors, Charles Payne and George L. Pierce; letters from his college roommate, fellow Iowan Chester C. Davis, a newspaperman and later head of the Agricultural Adjustment Administration and president of the Federal Reserve Bank in St. Louis; and a few letters from Ellergy Sedgwick, editor of Atlantic Monthly. Atlantic Monthly correspondence with both Nordhoff and Hall is on fifteen rolls of microfilm but unfortunately is not yet in the Archives.

Twenty-eight small notebooks contain Hall's travel notes, poems, outlines for stories, vocabulary lists (Icelandic and Polynesian), book and music lists, and other miscellany. World War I correspondence, photographs, and clippings provide significant material for the World War I scholar interested in the human aspect of and attitudes toward the war. These materials, together with the manuscripts, provide valuable resource for the researcher interested in the genesis of some of Hall's stories. They also provide insight into James Norman Hall as a person, world traveler, thinker, and writer of considerable stature.

EDITOR's NotE: In the spring of 1978 the library in the Division of Historical Museum and Archives in Des Moines received a collection of newspaper clippings, correspondence, and manuscripts by and about James Norman Hall, donated by Hall's 


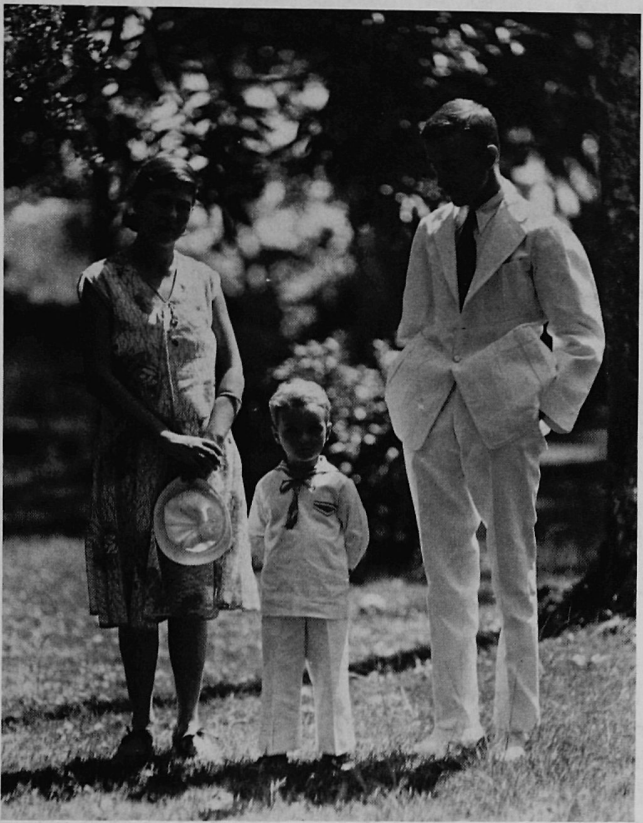

The Hall Family in 1930: Sarah Winchester, Conrad, and James Norman.

nephew and namesake, James Norman Hall II. The clippings contain reports of Hall's participation as a soldier and aviator during World War I. The letters span the years 1909-1951 and are largely original typescripts (with a few holographs). However, the bulk of the approximately 250 letters covers the mid1920 s to 1939 . Hall wrote almost monthly to his mother in Colfax, Iowa from his home on Tahiti. The letters detail his life on 


\section{The Annals of Iowa}

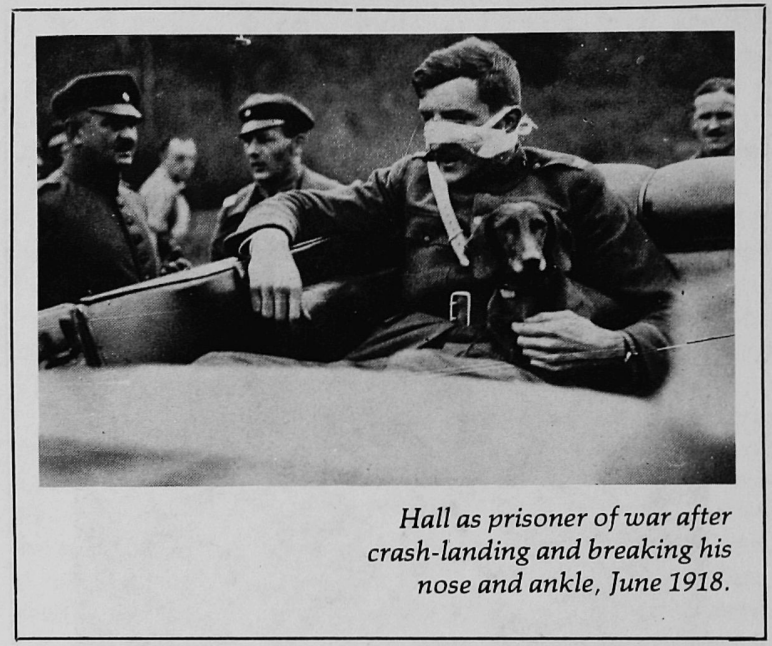

the island, his marriage in 1925 to Sarah Winchester, an English girl who had grown up in Tahiti, the birth and childhoods of their children, Conrad and Nancy Ella, and the research he and Charles Nordhoff engaged in while writing stories and novels with South Seas settings. Interspersed with his letters are a few written by his wife Sarah to Mrs. Hall and to Fred Hall, James Norman's brother. Included in the collection are about twenty photographs of Hall and friends during the war and of Tahitian people and scenes. The division was also presented with Hall's aviator uniform which is on display in the historical museum.

-J.G.

For more information on the James Normal Hall papers, write Anne G. Kintner, Archivist, Burling Library, Grinnell College, Grinnell, Iowa 50112, and Phyllis McLaughlin, Manuscripts Librarian, Division of Historical Museum and Archives, E. 12 and Grand, Des Moines, Iowa 50319. 
Copyright of Annals of Iowa is the property of State of Iowa, by \& through the State Historical Society of Iowa and its content may not be copied or emailed to multiple sites or posted to a listserv without the copyright holder's express written permission. However, users may print, download, or email articles for individual use. 